Gender and crime in the life pathways of young women offenders: Contrasting girls' and professionals' discourses.

https://link.springer.com/chapter/10.1007/978-3-319-73534-4_9

\title{
Raquel Matos
}

Universidade Católica Portuguesa, Centro de Investigação para o Desenvolvimento Humano

rmatos@porto.ucp.pt

\begin{abstract}
This chapter focuses on gender and crime in the life pathways of young women offenders through the analysis of the discourses of both young women serving prison sentences and professionals who deal with young offenders. In terms of theoretical framework, it is based on the feminist approaches that criticize, deconstruct and propose to rebuild the way women offenders have long been conceptualized in criminological theories.

The two empirical studies hereby presented were developed in Portugal. In the first, twelve young women prisoners (sixteen to twenty-two years old) were interviewed. In the second study, forty-three professionals who deal with youth delinquency on a daily basis were asked about their global perspectives on "youth delinquent groups" and their specific arguments about the involvement of girls in such groups. In both projects the interviews were recorded, transcribed and later analyzed under the grounded analysis principles. Various understandings of crime emerged from the young women's narratives about their life pathways, supporting the rejection of the traditional concepts of female juvenile delinquency. Such findings contrast with the gender stereotypes and ambivalence that seem to characterize the professionals' perspectives on female delinquency. According to them, "female characteristics" may prevent the involvement of girls in delinquent behavior or, on the contrary, make them «leaders» of deviant groups. Paradoxically, the professionals also suggest that there is a "lack of femininity" in girls who get involved in delinquency, particularly in delinquent groups such as gangs. Our findings emphasize the advantages of assuming a gender perspective and of putting in contrast different narratives on young women's delinquent behavior.
\end{abstract}

Key words: Gender, young women offenders, pathways, identity 


\section{Introduction}

In this chapter, two empirical studies developed in Portugal are presented in order to contrast young women offenders' perspectives with those of professionals on women's involvement in crime and deviance. They are based on the feminist approaches that criticize, deconstruct and propose to reconstruct the way women offenders have long been conceptualized in criminological theories. As these approaches claim, in these empirical studies a fundamental status was conferred to gender and to variables such as class and ethnicity, and no specific pre-conceptions (e.g., double deviance; irrationality) were adopted about the way women are involved in criminal activity. We begin by discussing the impact that those theoretical perspectives had on several empirical studies on women and crime that have been developed since the 1990s, both globally and in the specific context of Portugal. We then present the most relevant findings of both studies to discuss gender and crime in the pathways of young women offenders. We end the article by contrasting the discourses of young women inmates with those of the professionals. We conclude that the latter are shaped by gender stereotypes and, as such, do not consider the diversity of paths and forms of involvement in crime that are evidenced by the young women themselves.

\section{The feminist contributions to the study of women and crime, globally and in the Portuguese context}

The first theoretical approaches that aimed at understanding the female criminal behavior first appeared in the context of a highly positivist and androcentric late $19^{\text {th }}$ century criminology. Together with some of the psychological and sociological theories developed later on, also deterministic to female deviance (e.g., Pollak, 1950), these bio anthropological approaches prevailed as dominant models during the first half of the $20^{\text {th }}$ century. New perspectives on women as crime perpetrators were enabled by the incursion of the feminist movements in criminology after the 1960s (Matos \& Machado, 2012). However, it was only in the context of a more open and diverse late 1980s criminology (Gelsthorpe, 1997) that several feminist approaches started to re-contextualize female criminality in the criminology discourses (Carlen, 1987, 1988; Rafter \& Heidensohn, 1995; Smart, 1990/1996). Also in Portugal, following the international trend, some 
studies have been carried out since the 1990s to understand women offenders' trajectories and prison experiences from a feminist critical perspective.

To mention some of the most relevant literature, we can start with Cunha's (1994, 2002) ethnographic studies on women's experiences in Portuguese prisons. In a first approach, Cunha (1994) drew attention to identity and cultural aspects of women's experiences of imprisonment. Later on, she focused on women convicted for drug offences to analyze the intersections between the prison and the 'neighborhoods'. Among other findings, Cunha (2002) evidenced that imprisonment may emerge as an expected life transition in the trajectories of many women who come from the same marginalized neighborhoods. As she concluded, criminal activity based on the drugs market is common in the lives of women who do not have many other options in the 'normative job market' (Cunha, 2002).

Later on, Matos (2008) interviewed nearly all the women under 21 years old detained in the Portuguese prison system. The 49 interviews revealed several different pathways directing young women to prison. While some were in prison for violent crimes against a person but had no evidence of previous deviant behavior, drug use, or the involvement of relatives in crime, others convicted for various crimes, presented a past as drug users and had previous records of delinquency; in addition, some of their relatives had already been in prison. Others were serving time for drug trafficking, which was linked to problematic and continued use of hard drugs. Finally, some young women presented themselves as working women, whose lives did not escape the socially determined standards, except in their daily work in the narcotics trade. This study made it possible to question the stereotyped discourses about female crime not only because of the diversity of trajectories found but also because it allowed us to look at women as entrepreneurs in crime, as was the case with the latter example (Matos, 2008).

More recently we can highlight the work of Granja (2016), focused on the intersections between the experiences of incarceration and the prisoners' family relations. By taking a critical stance towards the dominant discourses that link family and crime, Granja (2016) evidenced how prison sentences have impacts that go far beyond the prison walls affecting family members who were not convicted. She also concluded that prison contributes to emphasize the gender asymmetries, which in turn reinforce the gender-related vulnerabilities on women's lives (Granja, 2016). 
The feminist perspectives that supported these national and many of the international studies on women, crime and imprisonment, criticized three fundamental ideas in the way discourses on women who commit crimes tend to be constructed.

The first is that women offenders are considered twice as deviant, for transgressing both the law and the conventional gender roles. As Cunha (1994) points out, the double deviance attributed to women is due to the fact that "the transgression of legality that has led to imprisonment is in one way or another concomitant with the denial of the norms that define appropriate female conduct" (p.24). Underlying the dual construction of the deviant woman is a 'dichotomous view of the feminine': on the one hand there is the "chaste, domestic and maternal" woman and on the other "the woman attending the public sphere, neglecting family and domestic responsibilities" (Cunha, 1994, p.24).

The second criticism concerns the narrow view of female criminality, focusing only on specific types of crime because of the dominant stereotypes. The stereotyped characterization of crimes committed by women thus contrasts with male crime, considered not only more frequent and violent, but also much more diverse (Matos \& Machado, 2012). This argument for the existence of 'typical female crimes' is seen by the feminist authors (e.g., Carlen, 1983, 1987) as having negative implications for women, including the way they are treated in the penal system. Studies that evidenced the heterogeneity of women's transgression (e.g., Matos, 2008) as well as the involvement of women in deviant activities traditionally associated to men, such as terrorist acts (Cruise, 2016) or gang violence (e.g., Campbell, 1992; Laidler \& Hunt, 2001; Miller, 2001) have contributed to the deconstruction of the argument of the specificity of female criminality. The feminist authors suggested that the differences between men and women offenders rested on the frequency and severity of the crimes rather than the type of crimes committed. In addition, they have argued that many differences in the statistics are particularly due to a differential structure of opportunities, to different forms of socialization and to gendered social control, than to 'innate characteristics of the offender' (Matos \& Machado, 2012).

Finally, the feminist perspectives criticize the construction of a transgressive woman who does not rationally choose to commit crimes. According to them, women who commit crimes have been unduly represented and treated as 'unstable and irrational' in the various traditional criminological approaches (Rafter \& Heidensohn, 1995). The argument of the hetero-determination of female criminal behavior has also been central 
in conventional discourses about the offending woman, described as committing crimes not by her choice, but coerced by others. Given such discourses, feminist authors have sought to deconstruct them through the exploration of social factors, such as the social and economic marginalization of women, patriarchal power and the informal devices for controlling women's behavior (Matos \& Machado, 2012).

The feminist conceptualization has been more difficult to find in studies that focus specifically on girls' delinquency. Indeed, when it comes to analyzing youth and delinquent behavior, many studies present a more positivistic and less critical epistemological framework. The approaches that explore socialization and gender roles, however, although sometimes remain close to a deterministic and stereotyped reading of female delinquency, have the merit of going beyond biology and the supposedly innate characteristics of women to include sociological dimensions.

An example is the analysis of girls' transgression from the point of view of how social expectations on them (e.g., subordination to men, compliance with the norms) may determine or constrain their own deviance (Matos, 2008). Other authors discuss the influence of a normative feminine socialization on girls' delinquency based on the argument that delinquent acts are related to an ideal of masculinity and to the roles conventionally attributed to men. According to them, boys' socialization tends to legitimate deviant acts while girls' socialization occurs in terms of compliance to the norms. On the one hand, it is suggested that girls' socialization promotes higher compliance than boys' socialization, because when committing delinquent acts girls are violating gender expectations. Some studies show, for example, that girls feel more shame and guilt when they get into trouble with the law and they legitimate delinquent acts less than boys do (e.g., Morris, 1965, cit. in Shoemaker, 2010). On the other hand, some authors argue that the delinquent acts committed by young women result from a socialization similar to men's, leading to participation in typically male roles, something that does not happen to non-delinquent girls (Shoemaker, 2010). In a more critical perspective, other authors suggest that young women who transgress move away from normative expectations of femininity. According to this perspective, when subjected to a more strict gender control, especially in the family context, girls can choose to break with the expectations of corresponding to an ideal of femininity that relies on them (Matos, 2008; Matos \& Machado, 2012).

In Portugal, among the studies on juvenile delinquency, we highlight the critical approach by Duarte (2012) on the trajectories of girls who comply with youth justice 
measures. Duarte systematizes four different trajectories for girls: those with a history of family victimization and violence, and significant paths in terms of deviant behavior and regulation by the control authorities ("Emphasized transgression"); the trajectories of girls who don't have a history of family victimization nor previous institutionalization, and whose transgression seems to be associated with the "rebellion of being young and trying to experiment" ("Rebel-transgression"); the paths of girls whose positioning in relation to their deviant behavior is hetero-determined, centered on factors which do not depend on themselves ("Transgression-influence"); and finally, the trajectories of girls whose deviant behavior assumes an exceptional character (Duarte, 2012). This study emphasizes the relevance of gender in girls' delinquent behavior and highlights differentiated social control and various forms of gender discrimination that the girls themselves associate with their delinquent paths.

As previously mentioned, the feminist perspectives on criminology brought new conceptualizations of the woman offender and, consequently, new focus and new methodologies for understanding female delinquency. Globally, several approaches have specifically targeted girls' criminal pathways (e.g., Carlen, 1987; Daly, 1994; Miller, 2001). However, in the Portuguese context, with the exception of the aforementioned study by Duarte (2012), we can say that these critical feminist approaches on feminine youth delinquency are still scarce. The studies we are about to present may also be seen as important contributions, as the first one focuses on the way young women offenders confer themselves meaning to their criminal experiences and the second analyzes the perspectives of the professionals on girls' deviant pathways.

\section{Girls' discourses: Life pathways, meanings of crime and identity construction in young women in prison}

This study is part of a research project about "life pathways, meanings of crime and identity construction in young women in prison"1. In this project we intended to understand how circumstances such as inequality of opportunities or gender relations were relevant constraints on the pathways of young female inmates (Matos, 2008). We conducted in-depth interviews with twelve young female prisoners, sixteen to twenty-two years old, selected after a preliminary study with 49 young women prisoners in Portugal.

\footnotetext{
${ }^{1}$ Research project funded by the Fundação para a Ciência e a Tecnologia (Foundation for Science and Technology) and by the Comissão para a Cidadania e a Igualdade de Género (Commission for Citizenship and Gender Equality) (PIHM-VG-0036-2008).
} 
As such a study evidenced different deviant experiences concerning the type of crime, previous deviant pathway, drug use and relatives' involvement in crime (Matos, 2008), for this study we selected young women with contrasting paths in those dimensions (Table I). The interviews were recorded, transcribed and later analyzed under the grounded analysis principles.

Table I: Participants, with a description of: crime, prison sentence, criminal record, drug use and relatives involved in crime

\begin{tabular}{|c|c|c|c|c|c|}
\hline Alias (age) & Crime & Prison sentence & $\begin{array}{l}\text { Previous } \\
\text { crimes \& } \\
\text { sentences }\end{array}$ & Drug use & $\begin{array}{l}\text { Family \& } \\
\text { crime }\end{array}$ \\
\hline Helga (22) & Trafficking & $\begin{array}{l}4 \text { years and } 6 \\
\text { months }\end{array}$ & $\begin{array}{c}\text { Assault } \\
\text { (without } \\
\text { conviction) }\end{array}$ & Cocaine & $\begin{array}{l}\text { Partner, } \\
\text { mother, father, } \\
\text { brother, sister- } \\
\text { in-law, cousin }\end{array}$ \\
\hline Iris (21) & Trafficking & $\begin{array}{l}3 \text { years and } 4 \\
\text { months }\end{array}$ & - & $\begin{array}{l}\text { Heroin } \\
\text { Cocaine }\end{array}$ & Partner, father \\
\hline Joana (22) & Trafficking & 4 years & - & - & Mother, sister \\
\hline Katia (19) & Trafficking & 4 years & - & - & - \\
\hline Dalia (19) & $\begin{array}{c}\text { Crimes against } \\
\text { property }\end{array}$ & 4 years & $\begin{array}{l}\text { Crimes against } \\
\text { property } \\
\text { (without } \\
\text { conviction) }\end{array}$ & Heroin & - \\
\hline $\operatorname{Emma}(21)$ & $\begin{array}{c}\text { Crimes against } \\
\text { property }\end{array}$ & $\begin{array}{l}3 \text { years and } 9 \\
\text { months }\end{array}$ & $\begin{array}{l}\text { Crimes against } \\
\text { property; } \\
\text { (18 months on } \\
\text { probation) }\end{array}$ & $\begin{array}{l}\text { Heroin } \\
\text { Cocaine }\end{array}$ & Partner \\
\hline Flora (20) & $\begin{array}{c}\text { Crimes against } \\
\text { property }\end{array}$ & 4 years & $\begin{array}{l}\text { Crimes against } \\
\text { property; } \\
\text { (3 years on } \\
\text { probation) }\end{array}$ & $\begin{array}{l}\text { Heroin } \\
\text { Cocaine }\end{array}$ & $\begin{array}{c}\text { Partner; } 2 \\
\text { brothers }\end{array}$ \\
\hline Guida (21) & $\begin{array}{c}\text { Crimes against } \\
\text { property }\end{array}$ & $\begin{array}{c}7 \text { years and } 6 \\
\text { months }\end{array}$ & $\begin{array}{l}\text { Crimes against } \\
\text { property; } \\
\text { (2 years in } \\
\text { prison) }\end{array}$ & $\begin{array}{l}\text { Heroin } \\
\text { Cocaine }\end{array}$ & $\begin{array}{c}\text { Partner, } \\
\text { father, cousin }\end{array}$ \\
\hline Alexandra (18) & Homicide & 6 years & - & - & Mother \\
\hline Bárbara (20) & Homicide & 4 years & - & - & - \\
\hline Carla (22) & Homicide & $\begin{array}{c}7 \text { years and } 9 \\
\text { months }\end{array}$ & - & - & Uncle \\
\hline Lisa (19) & $\begin{array}{c}\text { Crimes against } \\
\text { property } \\
\& \text { homicide }\end{array}$ & $\begin{array}{l}8 \text { years and } 9 \\
\text { months }\end{array}$ & - & - & Brother \\
\hline
\end{tabular}

From the analysis of the young women's discourses, some findings may be highlighted. To begin with, the girls themselves identify gender constraints that were negative turning points in their life pathways. For example, they report instances of rejection by their family for not behaving according to the expected gender roles. They also report being abused by male partners, as Helga said: 
"With him I couldn't say no. I was afraid. [...] If I didn't do what he wanted, I'd go home and be beaten. I think I wasn't even addicted to drugs anymore... it was the fear ... I had to make money.... I think the price I'm paying is too much because if I did it, it was out of fear, otherwise I wouldn't have done it." (Helga, 22)

Also worth mentioning is the diversity of life paths and deviant experiences of these young women. Their discourses reveal different narratives about their engagement in crime and deviance.

Some girls present very normative life courses, without any deviant occurrence up to the moment when the crime happens. Consequently, imprisonment is kind of a time-out in their lives and an obstacle to accomplish their main goal - to study and be successful. In this group, crimes are clearly gender-based. These girls' single criminal act could be the result of the experience of being sexually abused, subject to strict control by the family related to being a girl, or the lack of means to deal with an unwanted pregnancy. In fact, this is the only group where gender and crime are associated in a relevant manner. On the one hand, these girls present normative paths characterized by the acceptance of the gender norms. Paradoxically, the gender norms are at the basis of the crimes they committed, as Barbara's words clearly illustrate:

"I've always been a good student. As a little girl, I always wanted to study... and I still do. I wanted to study so badly that I even skipped First Grade. I've always believed that 'you can never learn too much' and I still do believe it now; As far as my path in prison is concerned, everything is running smoothly. I like to do stuff, to participate, to lead, I have had a few ideas and I have implemented a lot of projects in here [...] I have joined reading sessions, the soccer team, I do gym ....I have already done a play..." (Barbara, 22)

Other young women present themselves as victims, of abuse during childhood, or "of drugs" or of violent partners later in their lives. They adopt a 'pathological' perspective of their own transgression, describing being out of control and excluding any agency and rationality from their involvement in crime. In the case of Dalia, as she describes, it was the drugs that took over her life: 
"If I wanted to stop I couldn't do it. In order to use drugs I had to steal [...] all I cared about was drugs, that was all I cared about [...] I was a drug addict...My life was all about drugs." (Dalia, 19)

Some confer meaning to crime describing a rational choice for the criminal activity and the idea that they would again take the same option, showing no regret. In terms of criminal experience, they dedicate themselves to drug trafficking, without using drugs. Their involvement in crime is not ruled by a criminal lifestyle; instead, it is governed by a style close to normative patterns. Drug trafficking is, however, the activity they choose to make money, not only for paying their bills, but also for a better life which, according to their statements, would be difficult to reach by simply performing other available activities. Take, for instance, the words of Katia about her involvement in trafficking: "I wanted to have everything, just like everybody else had. I've always been like this; whenever I go past a clothes shop I want it all.” (Katia, 19)

Finally, some girls' statements on their life trajectories, and particularly on delinquent behavior, lead us to associate them with the construction of deviant identities. They already have a significant track in terms of delinquency and contacts with the youth justice system and their delinquent activity is heterogeneous, with particular incidence on crimes against property. These girls present themselves as users of the so-called 'hard' drugs, although they refer that they have never lost control over their drug use. They constantly refer to this dimension of control, when using expressions such as being "proud" of surviving in the streets or "being capable of stopping their use of drugs". Deviance seems to be a way for these young women to gain control over their lives (Batchelor, 2005a). We also found, implicit in their statements, a dimension of pleasure and excitement associated with crime, which leads us to the positive feelings taken from criminal action proposed by Katz (1988/1996) and found in other studies on young women offenders, like the work of Batchelor (2005b). This dimension of pleasure is revealed through a 'street life' discourse, characterized by a marginal lifestyle, by the association with deviant peers with whom they use drugs and survive in the streets, by sleeping in uncertain places and by an intense nightlife. Take the words of Emma below:

"This was our lives for many years, we stole a lot of money and then we went, bought and smoked [...] we always had money, we always had drugs; life always felt good. You know what street life is like ... there's drugs and stuff and here and there ... it may take one, two, three years, four, five years or more, but there will 
be one day, if you keep living on the street, there will be one day when you will... touch it. [...] We lived in sort of abandoned houses, [...] we managed to set up the water [...] We even had a key because we installed a locker. [...] I had to take care of myself, I had to do all this stuff ... I have no complaints. After all I did well, am I right?" (Emma, 21)

The diversity of these narratives allowed to deconstruct the idea of a typically female criminality, so criticized by the feminist perspectives in criminology. In addition to the four pathways previously identified, Lisa's particular case shows the combination of extreme meanings of crime: related to a criminal lifestyle or as an exception in a 'normative' pathway.

"I had a schedule, on Fridays and Saturdays...at night...because those were the days when I had my parents' permission to go out...was when I robbed, and during the rest of the week my days were perfectly normal. If I had to, I went with my school friends to a disco or a bar or something like that, and only when they went home I would go and meet the group [...] It's that adrenaline feeling, the thought of getting caught. Danger gives me a real thrill..." (Lisa, 19)

In this case, a single trajectory contains several ways of conferring meaning to crime, oscillating between normative and deviant identities. Analyzing this case leads us to the conclusion that it is impossible to reduce female transgression to one given typology; despite the regularities identified in the discourses of the different women, each of their pathways is idiosyncratic (Matos, 2008). Based on this study it is also possible to state that young women's transgression is quite further from the most traditional conceptions, hence it makes sense to refuse the gender stereotyped approaches to this phenomenon. In fact, the emerging narratives evidenced that, most of the times, (juvenile) female criminality is not quite as apart from the male deviant experiences (Batchelor, 2005b). This finding shows that even the expression 'female criminality' should scarcely be used, in order to avoid reinforcing the traditional argument that there is women-related criminality. 


\section{Discourses of professionals on the involvement of girls in delinquent groups}

The second study was part of a research project about 'youth delinquent groups' (Matos, Almeida, \& Vieira, 2014) ${ }^{2}$, with the purpose of analyzing how practitioners dealing with young offenders characterize the phenomenon of youth delinquent groups in Portugal. Forty-three professionals (Table 2) working in the main Portuguese urban areas were interviewed. As in the precious study, the interviews were recorded, transcribed and analyzed under the grounded analysis principles. In this chapter, we will focus only on the practitioners' discourses on the involvement of girls in delinquent groups.

Table 2. Number of participants, according to the type of institution where they work

\begin{tabular}{|c|c|}
\hline Type of Institution & Number of Participants and Roles \\
\hline $\begin{array}{l}\text { Justice System } \\
\qquad(\mathrm{n}=16)\end{array}$ & $\begin{array}{c}\text { Six Police Officers } \\
\text { Four Magistrates } \\
\text { Six Youth Justice practitioners }\end{array}$ \\
\hline $\begin{array}{l}\text { Protection System } \\
\qquad(\mathrm{n}=8)\end{array}$ & $\begin{array}{l}\text { Four practitioners from Child Protection Services } \\
\text { Four practitioners from Children Emergency Shelters }\end{array}$ \\
\hline $\begin{array}{l}\text { Community Institutions } \\
\qquad(\mathrm{n}=14)\end{array}$ & $\begin{array}{l}\text { Five practitioners from schools } \\
\text { Nine practitioners from Community Intervention Projects }\end{array}$ \\
\hline $\begin{array}{l}\text { Universities } \\
\quad(\mathrm{n}=4)\end{array}$ & Four academic researchers \\
\hline $\begin{array}{l}\text { Other institutions } \\
\qquad(\mathrm{n}=1)\end{array}$ & One Clinical Psychologist \\
\hline
\end{tabular}

Based on the analysis of the practitioners' discourses, emphasis will now be put on their conceptualization of the involvement of girls in delinquent behavior.

To begin with, the participants tend to portray the youth gangs as a "boys" phenomenon and to depict girls as having other types of deviant behaviors, namely "running away from home" or "early pregnancy". According to this perspective, illustrated by the words of a woman working in protection services, belonging to a gang is an essentially male phenomenon: "Boys. Boys. Girls have different deviant behaviors [...] Gang members are boys. The boys." (Woman, 42, Protection Services). The idea conveyed here that there is a boys' delinquency and a girls' delinquency is also present

\footnotetext{
${ }^{2}$ Research project funded by the European Commission (JLS/2009-2010/DAP/AG/1370)
} 
in the discourses of other professionals. Take, for instance, the words of a woman working at a community institution:

"...I think girls have a different way of...even the female delinquency is a little different from the male delinquency, isn't it? I think they are a little more subtle, I don't know... I think girls' delinquency at this age is more a matter of shoplifting, at least here, what we register is shoplifting perfumes, stealing from school, stealing from the other girls..." (Woman, 41, Community Institutions)

These references reveal the same tendency found in the classic approaches to crime, which associate women to 'typically female deviances'. This trend is based on gender stereotypes and on the idea that there are male and female crimes (Matos \& Machado, 2012).

When they characterize the girls that join juvenile gangs, several professionals mention qualities that, in their opinion, are "typically feminine". On the one hand, they argue that there are characteristics that differentiate girls from boys, such as, for example, being more "manipulative", "strategist", "subtle" and "seductive". On the other hand, the professionals mention that the girls try to take advantage from their "female condition". This is well illustrated by the words of a 35 year-old woman working in the Justice System: "They have a mind of their own, they know how to use their girlish attributes to rule... ahm.... and they do it with, how do we say it, with an iron fist, right?" (Woman, 35, Justice System).

There are also professionals that argue that girls who join gangs step away from the "female standard", becoming more masculine than expected. A woman working at a community institution says that "it depends on the girls we are talking about because there are some manly girls, right? [...] There are girls who present themselves as actual boys and, in those cases, the difference is not that big" (Woman, 32, Community Institutions).

Considering the role girls play as gang members, some practitioners refer it is different from the role played by boys. As two participants report, girls do not take leadership, but keep secondary roles:

"Quite often their role is secondary, we don't see them as leaders. I can't imagine that in a group composed by boys and girls, I can't imagine a girl being the leader. Ahm, I think in that case boys will stand out and will sort of keep that position. 
Probably do not lose, do not let the power of being a, in quotation marks, leader, slip from their hands." (Woman, 35, Protection System); "I honestly think they play a limited role because they end up being the wives, the girlfriends..." (Woman, 28, Community Institutions).

There is also the idea that girls are sometimes "strategically used by boys" for diverse purposes such as, for example, "to outwit the police". Take the words of two professionals below:

"If you see a vehicle late at night with four people inside it may be a bit suspicious. If you see two couples inside the vehicle, it no longer becomes suspicious (...) these days many women are used." (Man, 41, Justice System)

"A girl helps to disguise ... We are less suspicious of girls. So it may be useful to have girls in the group." (Woman, 47, Academia)

The perspectives these professionals share, both about the passive and peripheral role girls play in gangs and about their instrumentalization in these groups, are in line with the concept of the “object girl” (Luchinni, 1997, cit. in Duarte, 2012).

But the dominant trend is to present dichotomized perspectives on girls' delinquency, just like it happens in the most traditional criminological discourses. As we saw, on the one hand, many practitioners say that women offenders have 'typical female attributes" - they are "strategists", "subtle", "experts in seduction" - and that they know how to take advantage from those attributes. On the other hand, many participants consider that young women offenders are "less feminine" and "similar to boys". They may even be "worse than boys", "more violent" and "fearless". Two women working in the Justice System make clear statements about this:

"[...]In cases that I have worked, women end up acting in a much more primary way, hit more, and hit each other more and have a very clear sense of burglary and theft; They can steal in a more shocking way compared to many boys." (Woman, 40, Justice System)

"I think we still have less violence because there aren't many girls (offending); when we start having more I think we'll have more violence [...] I think that girls are much more capable to act violently and to enhance physical aggression [... ] " (Woman, 35, Justice System) 
Overall, from the analysis of the practitioners' discourses on the involvement of girls in delinquent groups, stereotyped ways of giving meaning to the girls' behaviors were evidenced. These stereotyped perspectives seem to worsen when it comes to deviant behavior, which tends to be even more subject to bias. In addition, the findings revealed that the participants tend to present perspectives shaped more by gender stereotypes when they work in the formal justice system, when compared to those who work more closely to the communities.

\section{Contrasting discourses of girls and professionals}

Though we brought into discussion two distinct studies, with different aims and participants and with a time gap, we believe that contrasting them is relevant and may give us interesting insights about gendered perspectives on young women's transgression.

The first one is that there were some convergences in the perspectives of the young women offenders and of the professionals. Both groups adhere, to some extent, to the dominant discourses on women and crime. Even those girls with a "criminal lifestyle", distant from the image of a "good girl", tend to adhere to the dominant conceptions of femininity, like the central role of motherhood or of family life, when describing themselves. In addition, for both groups, hesitations were found between a perspective embodied in stereotypes and in the dominant discourses of femininity and a more critical perspective outside such discourses.

Still, divergences are worth mentioning. First of all, various understandings of crime emerged in the young women's narratives, supporting the rejection of the traditional concepts of female delinquency. These diverse understandings contradict the idea that there are specific "female crimes". And the diversity in their interpretations and positioning regarding delinquency also contradicts traditional views on women and crime. In turn, the dimension of rationality associated with crimes committed by some young women contradicts the argument of its pathology or madness.

Such findings contrast with the gender stereotypes and ambivalence that prevail in the professionals' perspectives on female delinquency. According to them, "female characteristics" may prevent the involvement of girls in delinquent behavior or, on the contrary, make them "leaders" of deviant groups. Paradoxically, the professionals also 
suggest that there is a "lack of femininity" in girls who get involved in delinquency, particularly in delinquent groups.

Thus, gender stereotyping and ambivalence that have dominated, for quite some time, the discourses on female delinquency seem to persist among those who deal on a daily basis with young offenders. Also worth mentioning is the fact that among the professionals, the closer they are to the Justice System, the more stereotyped their narratives are. That means that police officers and magistrates present more penalizing discourses about women and crime than the practitioners working in communities or in the protection system.

To sum up, we highlight in the first place that the findings from both studies reinforce our questioning about the traditional approaches to female criminality. The diversity in the life paths and in the deviant experiences of all the women included in our sample contradict the idea that there are specifically "female crimes", which is one of the main criticisms to traditional, social and scientific arguments on female transgression (Rafter \& Heidensohn, 1995). The heterogeneity of the meanings and stances women assume regarding their deviant behavior, namely regarding the dimension of pleasure that sometimes seems to be underlying deviance, also contradict the traditional look at women and crime. In turn, the dimension of rationality associated with the crimes perpetrated by certain young women goes against the argument of their pathology or insanity.

Some of the attitudes towards deviation that have been identified show that the criminality of young women seems to come closer to the criminality that is traditionally associated with boys, either due to the diversity of criminal experiences, or specifically due to the criminal lifestyle noticed in certain women. However, no changes regarding the women's own dominant conceptions of femininity are noticeable (e.g., motherhood central role, family life). Women who commit crimes are still considered doubletransgressors, which actually reflects on their discourses about crime in their life pathways.

On the other hand, the analysis of the professionals' discourses reveals a contrasting scenario as their conceptualization of female transgression is often in line with the most traditional discourses about criminology.

The analysis of the professionals' perspectives brings to light a look at female delinquency largely framed by gender stereotypes. To begin with, by the belief that the 'female woman' is not violent and, for that reason, female delinquency is perpetrated by 
women who deviate from the ideal of femininity. By doing so they are considered "worse than men", more violent, more cruel. We are then faced with the classic argument that the female representation tends to be dichotomized; consequently, when a woman commits a crime, she goes quickly from "angel to demon" (Matos, 2008). It seems a paradox, but the gender stereotypes are present not only in the idea that there are 'typically female' crimes, such as "shoplifting", which was defended in criminological theories from the first half of the $20^{\text {th }}$ century (e.g., Pollak, 1950), but also in the argument that there are 'typically male' delinquent activities, for instance gang membership. Such stereotypes also mark the discourse on the tendency for girls to join gangs because of their dating relationships and on how boys 'use' them within the gangs' activities, exactly the way it will happen in the gender relationships established in any given context.

Therefore, we find that both the gender stereotypes and the ambivalence that characterize the discourses on female delinquency remain present and will also have an impact on the specific look at the participation of girls in gangs. It is noticeable in "typically feminine" characteristics that may bring advantages for the gangs and in the "lack of femininity" of the girls who get involved in gangs. It is noticeable in the "feminine characteristics" that prevent them from playing a leading gang role or, on the contrary, that turn them into leaders, organizers and strategists or even "worse than them" for having "less fear", "incite to more violence", and for "being colder".

\section{Conclusion}

To conclude, our first remark converges with what we have said in some of our previous work on women, crime and imprisonment (e.g., Matos, 2008; Matos \& Machado, 2012): we still need to look at girls' and women's transgression through a gender lens. The work with the young women in prison evidenced that those who are more conformed to the traditional gender roles seem to be more vulnerable to crimes related to their female condition. It also showed that a strict social control in the family context may lead the girls to forms of delinquency traditionally associated with boys. On the other hand, the study with the professionals has shown that their perspectives on girls' delinquency may be highly shaped by gender stereotypes. It was interesting to see the divergences between the discourses of girls with delinquent behaviors and those of the professionals who deal with them. In fact, the diversity of paths and meanings of crime presented by the girls seems to be constructed as a dichotomy by the professionals. As 
we have seen, just like in the classical criminology approaches, they tend to see delinquent girls as mere 'objects in the hands of their male counterparts' or as evil women who are worse than males who commit crimes.

The final remark is about the fact that the professionals' discourses are more stereotyped the further they are from the communities. This evidence suggests the importance of bringing judges and prosecutors as well as other staff from the formal justice system closer to the communities. Possibly, if the professionals are closer to the communities, the process of constructing narratives about delinquent behavior and pathways is more informed by those who are part of it and who, at some point in their lives, may pass through the justice system.

\section{References}

Batchelor, S. (2005a). 'Prove Me the Bam!' Victimisation and agency in the lives of young women who commit violent offences. Probation Journal, 52(4), 358-375. doi: $10.1177 / 0264550505058034$

Batchelor, S. (2005b, July). 'Fer the Buzz o' It?'. The excitement and emotionality of young women's violence. Paper presented at Annual Conference of British Society of Criminology, Leeds, United Kingdom.

Campbell, A. (1992). Girls in the gangs. Cambridge: Blackwell Publishers

Carlen, P. (1983). Women's Imprisonment. A study in social control. London: Routledge \& Kegan Paul.

Carlen, P. (1987). Out of care, into custody: Dimensions and deconstructions of the state's regulation of twenty-two young working-class women. In P. Carlen \& A. Worrall (Eds.), Gender, crime and justice (pp. 126-160). Buckingham: Open University Press.

Carlen, P. (1988). Women, crime and poverty. Milton Keynes: Open University Press.

Cruise, R. (2016). Enough with the Stereotypes: Representations of Women in Terrorist Organizations. Social Science Quarterly, 97(1), 33-43. doi:10.1111/ssqu.12250

Cunha, M. I. (1994). The Fabric of Confinement. Identity and Sociality in a Women's Prison (Vol 1). Lisboa: CEJ.

Cunha, M. I. (2002). The Prison and the Neighborhood. Traffincking and Trajectories (Vol. 1). Lisboa: Fim de Século. 
Granja, R. (2016). Beyond prison walls. Probation Journal 63(3), 273 - 292. doi: $10.1177 / 0264550516648394$

Daly, K. (1994). Gender, crime and punishment. New Haven: Yale University Press.

Duarte, V. (2012). Discursos e Percursos na Delinquência Juvenil Feminina. Famalicão: Editora Húmus.

Gelsthorpe, L. (1997). Feminism and criminology. In M. Maguire, R. Morgan, \& R. Reiner (Eds.), The Oxford handbook of criminology (pp. 511-534). Oxford: Clarendon Press.

Katz, J. (1988/1996). Seductions and repulsions of crime. In J. Muncie, E. McLaughlin, \& M. Langlan (Eds.), Criminological perspectives. A reader (pp. 145-159). London: Sage Publications.

Laidler, J., \& Hunt, G. (2001). Accomplishing femininity among the girls in the gang. British Journal of Criminology, 41(4), 656-678. doi: 10.1093/bjc/41.4.656

Matos, R. (2008). Vidas Raras de Mulheres Comuns: Percursos de vida, Significações do crime e Construção da identidade em jovens reclusas. Coimbra: Editora Almedina.

Matos, R., Almeida, T., \& Vieira, A. (2014). Questões de Género em Gangues juvenis em Portugal. Perspetivas de atores que intervêm no fenómeno. In V. Duarte \& M. Cunha (Coords.), Violências e Delinquências juvenis femininas: género e (in)visibilidades sociais (pp. 115-140). Famalicão: Editora Húmus.

Matos, R., \& Machado, C. (2012). Criminalidade feminina e Construção do género. Emergência e consolidação das perspectivas feministas na Criminologia. Análise Psicológica, XXX (1-2), 33-47.

Miller, J. (2001). One of the guys. Girls, gangs and gender. New York: Oxford University Press.

Pollak, O. (1950). The criminality of women. Philadelphia: University of Pennsylvania Press.

Rafter, N., \& Heidensohn, F. (1995). International feminist perspectives in criminology. Engendering a discipline. Buckingham: Open University Press.

Shoemaker, D. (2010). Theories of Delinquency. New York: Oxford University Press.

Smart, C. (1990/1996). Feminist approaches to criminology or postmodern woman meets atavistic man. In J. Muncie, E. McLaughlin, \& M. Langlan (Eds.), Criminological perspectives. A reader (pp. 453-465). London: Sage Publications. 
